УДК 349.22

DOI https://doi.org/10.32837/pyuv.v1i4(29).400

В. Ю. Пряміцин

orcid.org/0000-0002-6525-2087

викладач кафедри публічного права

Національного технічного університету України

«Київський політехнічний інститут ілені Ігоря Сікорського»

С. В. Ланкін

orcid.org/0000-0002-3513-5971

студент II курсу юридичного факультету

Національного технічного університету України

«Київський політехнічний інститут ілені Ігоря Сікорського»

\title{
ЗАХИСТ ТРУДОВИХ ПРАВ ПРАЦІВНИКІВ У НЕОФОРМЛЕНИХ ТРУДОВИХ ВІДНОСИНАХ
}

Актуальність. Відповідно до звіту Голови Державної служби з питань праці за 2018 рік в Україні було виявлено 25179 робітників, допущених до роботи без належного оформлення трудових відносин, із виявлених порушень під час перевірок службою на другому місці за кількістю знаходяться порушення у сфері укладання та розірвання трудових договорів, більше тільки з приводу виплати заробітної плати [7]. Здебільшого це спровоковано низьким рівнем життя та правосвідомістю суспільства, що не мотивує звичайних працівників захищати самостійно або звертаючись до державних органів власні права, встановлені трудовим законодавством. 3 іншого боку, це пов'язано 3 неефективністю та відсутністю інтересу держави в боротьбі з незадекларованою працею, що спровокована кризовим становищем державних інституцій і некомпетентністю державних службовців в Україні.

Предметом статті є захист трудових прав працівників у неоформлених трудових відносинах.

Метою статті $є$ виявлення основних чинників виникнення неоформлених трудових відносин, винайдення шляхів їх подолання та надання пропозицій до законодавства України задля подолання цієї проблеми.

Конституція України у ст. 43 встановлює можливість кожного громадянина працювати задля забезпечення власних соціальних і духовних потреб у самореалізації в суспільстві. Відповідно держава встановлює для себе обов'язок повного сприяння у всіх можливих аспектах реалізації цієї можливості та забезпечує відповідно до принципу рівності вільний вибір кожному місця роботи, способу заробітку тощо. Також одним із основних завдань, які держава гарантує власним громадянам, є програми з перекваліфікації або перепідготовки відповідно до кадрових потреб у державі [1].

Закон також встановлює перелік положень у сфері трудового законодавства, порушення яких призводять до притягнення винної особи до матеріальної відповідальності, оскільки, наприклад, передбачається:

1. За допуск працівника до роботи без оформлення трудового договору - штраф у розмірі тридцяти мінімальних заробітних плат (141 690 грн станом на 2020 рік);

2. За недотримання мінімальних державних гарантій в оплаті праці - у розмірі десяти мінімальних заробітних плат (47 230 грн станом на 2020 рік);

3. За порушення виплати заробітної плати, інших виплат або виплата їх не в повному обсязі з простроченням їх більш ніж на один місяць у трикратному розмірі мінімальної заробітної плати [3].

Такі великі суми пояснюються тим, що держава ставить собі за мету запобігти порушенню трудових прав громадянина та компенсувати порушення у їх прямому грошовому еквіваленті, таким чином покаравши недобросовісного роботодавця та повернувши отримані від експлуатації гроші.

Аналізуючи основні права та гарантії, надані законодавством України громадянину, потрібно особливо серед них виділити:

1. Право на належні та безпечні умови праці, що проявляється у встановленні 40-годинного робочого тижня, недопущенні до роботи, яка може завдати шкоди здоров'ю та життю людини, соціальному забезпеченні людей, що працюють на роботі, яка шкодить їх життю.

2. Захист від незаконного звільнення та гарантування виплати мінімальної заробітної плати. Кодекс Законів про працю України встановлює вичерпний перелік підстав звільнення працівника. Звільнення з будь-яких інших підстав забороняється і може мати наслідком оскарження цього рішення у суді та поновлення працівника на роботі та притягнення роботодавця до відповідальності. 
3. Особливими категоріями працівників вважаються жінки та неповнолітні діти, яким трудове законодавство встановляє облегшені умови праці через їхні біологічні особливості. Зазначеним соціальним групам гарантується працевлаштування у разі звільнення з обставин, що не залежать від них, у разі реорганізації або ліквідаціі підприємства.

4. Окремо закон встановляє виплату вихідної допомоги працівнику відповідно до відпрацьованого ним часу роботи, днів, конкретно виконаних завдань тощо [3].

Другим важливим аспектом є мінімальна заробітна плата, яка переглядається щорічно державою та встановляється у поточному Законі України «Про державний бюджет» з зазначенням ï̈ у конкретному гривневому еквіваленті. Ця цифра $\mathrm{e}$ тим соціальним бар'єром, нижче якого роботодавець не має права платити працівникові за місяць праці.

Важливим є своєчасне отримання заробітної плати, що б забезпечувало основну ціль праці працівника - задоволення своєчасно власних побутових потреб і необхідних для життя ресурсів, як, наприклад їжа, одяг, житло тощо.

Перерахувавши основні положення, які гарантує Конституція України, треба розуміти, наскільки ефективно ці норми втілюються в життя у правовідносинах між роботодавцем i працівником.

Зокрема, основною проблемою для українського суспільства виступає саме небажання роботодавців дотримуватися вказаних положень, що призводить або до численних порушень встановлених законом соціальних гарантій для працівника, або взагалі до відсутності будь-якого факту підтвердження трудових відносин безпосередньо через трудовий договір.

Це призводить до необхідності поновлення порушених прав шляхом звернення до уповноваженого державного органу з питань праці або до суду. Наявність трудових відносин у такому разі потрібно доводити опосередкованими доказами, зокрема встановленням факту виконаної роботи, отримання плати за систематично виконувану роботу, наявності трудового розпорядку на підприємстві тощо.

Важливо буде зазначити позицію науковців із приводу обов'язковості оформлення трудового договору при прийнятті на роботу. Так, I.O. Гуменюк зазначає, що через недостатність правового регулювання процедури укладання трудового договору породжується невизначеність у трудових відносинах між працівником і роботодавцем, оскільки, наприклад, трудовим договором може виступати як класична трудова угода, так і внутрішній наказ на підприємстві про прийняття на роботу. У сучасному законодавстві є пропозиції обов'язкового укладання саме договору в усіх випадках трудових відносин, але ця пропозиція не подає надій, адже через відсутність саме правильного механізму фіксації та доведення наявності фактичних трудових відносин за відсутності цього закріплення юридично введення цієї норми погіршить і так невтішне юридичне становище працівників в України з позиції захисту власних трудових прав [9].

Гарним прикладом є позиція А.О. Горденюка з приводу зловживання роботодавцями таким поняттям, як «умова про випробування», хоча, як зазначає науковець: «Одностороннє встановлення власником умови про випробовування є недопустимим». Однак роботодавці часто включають випробування в трудовий договір або контракт, а також у заяву або наказ при прийнятті на роботу тощо. Тобто у разі відмови працівником проходити випробовування на роботі, яка цього не потребує через наявний у нього стаж роботи або низьку кваліфікацію, це сприймається як відмова від укладення трудового договору [8]. Негативною стороною для працівника є те, що роботодавець може не зазначати про випробовування безпосередньо при початку роботи, а після того, як спливає два тижні повідомити про це працівника та не виплачувати жодних виплат за пророблену роботу.

Прогалини трудового законодавства України часто стають причиною обмеження прав і гарантій працівника та не виправдовують власної цілі, цьому сприяє багато факторів. Зокрема, основними чинниками, що спричиняють незадекларовану працю, є:

1. Архаїчність трудового законодавства України та недетальність врегулювання, тобто усі положення, вказані Конституцією України, більш детально конкретизуються лише у Кодексі Законів про працю України УРСР 1971 р. Зважаючи на те, що з моменту видання цього кодифікованого акта минуло більш ніж 50 років, користування ним як юридично ефективним регулятором вже неможливо, оскільки більша кількість явищ 3 часом або не має потреби в регулюванні через мінливість суспільства, або виникають нові суспільні явища, відносини між якими мають бути врегульовані. Як-от, робота по сумісництву визначається у ст. 102-1 КЗПП України лише в частині її оплати [3], із приводу відпочинку, робочого часу, та інших більш конкретних положень закон не встановляє, що примушує роботодавця регулювати на власний розсуд відносини між ним і працівником, який працює на декількох робочих місцях одразу [10].

2. Наступним чинником, що спричиняє незадекларовану працю в Україні, є небажання роботодавця виконувати обов'язок по сплаті податків за найманих працівників. Кажучи 
конкретно про податки на працівника в Україні, лише один внесок до Пенсійного фонду України щомісячно задля забезпечення соціального страхування населення відповідно до Закону України «Про обов'язкове соціальне страхування» становить більше $20 \%$ від заробітної плати працівника та має бути включений до неї, враховуючи також податок на доходи фізичних осіб поряд із військовим збором. Сума, яку повинен сплатити роботодавець за наявність належним чином оформленого працівника, наближається до половини з його заробітної плати загалом. Зважаємо знову на зазначений рівень мінімальної заробітної плати, нижче якої працівник не може отримувати оплату за виконану роботу, й отримуємо доволі велику суму, яку сумлінний роботодавець повинен сплатити до державного бюджету. Але зважаючи на певні економічні та соціальні чинники, повна реалізація оподаткування потребує постійного нагляду податкових державних органів, адже випадки недоотримання до бюджету грошових коштів через недбалість роботодавців є непоодинокими, питання також у тому, скільки випадків ухилення від сплати податків залишається невідомими та потребують виявлення та притягнення до відповідальності правопорушників.

3. Передумовою несплати податків до бюджету є низька правова культура суспільства, неефективна робота державних органів 3 питань праці та податкових органів, незнання працівником навіть положень Конституції України.

Все це призводить до зловживання роботодавцем власними правами та невиконання обов'язків, покладених на нього законом.

Станом на 2019 рік згідно з опитуванням, проведеним у КПІ ім. Ігоря Сікорського, близько 70\% респондентів, більше половини з яких студенти, хоч раз у житті працювали не офіційно [5]. Це засвідчує, що працювати неофіційно стає тенденцією серед молоді та сприймається як нормальна поведінка. Опитування свідчить про таке:

1. Близько $65 \%$ респондентів констатували факт порушення їх прав роботодавцем, що свідчить про те, що станом на 2019 рік серед молоді України переважна більшість, хоча й обізнана у власних правах та обов' язках, але, зважаючи на загальні економічні чинники, вимушена терпіти порушення роботодавцем встановлених законом гарантій на відпочинок, оплату праці, відпустку тощо, заради заробітку хоча б мінімальних коштів на проживання.

2. Позитивним $є$ обізнаність громадян у власних правах, адже близько $59 \%$ респондентів кажуть про те, що власні права й обов'язки більшість працівників усвідомлюють і прагнуть захистити та сумлінно виконувати власні обов'язки, дотримуючись закону. 3 іншого ж боку, третина респондентів не мають точного розуміння про власні трудові гарантії, встановлені законом. Це дає можливість роботодавцеві зловживати незнанням працівника трудового законодавства й експлуатувати його у власних цілях, що, як зазначалося, заборонено законом.

3. Також важливим є не стільки розуміння детально власних прав та обов'язків, а доступність інформації про можливість звернення до державного органу задля захисту власних прав і притягнення роботодавця до відповідальності. Відповіді розділилися майже порівну, де 48\% зазначає, що знають, куди звертатися у разі порушення власних прав, але не зверталися з невідомих причин, i невелика група, яка знала про існування державних органів з питань праці та реально туди зверталася. Інші з $52 \%$ респондентів не знають, куди їм звертатися у разі порушення їх власних прав або невиконання роботодавцем власних обов'язків, половина 3 яких звернулася би за нагоди [5].

Як вже зазначалося, загальні тенденції українського суспільства породжують численні порушення трудового законодавства, оскільки така маргінальна модель поведінки стає усталеною у суспільстві та надалі сприймається громадянами як нормальна. Основними шляхами боротьби 3 цією проблемою є запровадження державою програм із підвищення правової свідомості, покращення ефективності роботи наглядових органів із питань праці, підвищення інтересу громадян до власних прав та обов'язків, які надані їм державою, ініціатива працівників задля захисту власних прав. Це може виражатися у створенні програм підвищення правової освіченості у мережі Інтернет при співпраці з Міністерством соціальної політики України або Державною службою України з питань праці, ведення правової політики держави через соціальні мережі, введення обов'язкової вимоги про знання основ трудового законодавства на законодавчому рівні при прийомі на роботу тощо.

Одним з основних напрямів роботи державних органів з питань праці є боротьба з незадекларованою працею. Так, відповідно до Меморандуму, укладеного між Міністерством юстиції України та Державною службою України з питань праці, основною метою їх співпраці є докладання спільних зусиль щодо формування сприятливого середовища на ринку праці, що виражається у створенні робочих місць із достатньою заробітною платою та з безпечними умовами праці, забезпечення реалізації державної політики у сфері запобігання порушення законодавства про працю як роботодавцями, так і працівниками. Це виражається у проведенні конкретних заходів, спрямованих на вдосконалення контролю за оформленням трудових відносин із найманими 
працівниками, особливо на рахунок роботодавців, щодо яких відкрито виконавче провадження з приводу заборгованості з виплат заробітної плати [4].

Зважаючи на широке визначення «проведення конкретних заходів на вдосконалення контролю», ми вважаємо, що покращення у боротьбі 3 неофіційним працевлаштування повинно виражатися у виданні конкретних підзаконних актів про проведення перевірок або притягненні до реальної майнової відповідальності недобросовісних роботодавців, що дасть дійсно ефективні результати 3 погляду виконання принципів закону та позбавлення ринку праці від засилля незадекларованої праці, зловживання роботодавцями власними правами.

Важливою також є умовність цього Меморандуму, адже сам по собі він ніяких зобов'язань на центральні виконавчі органи влади навіть у межах власних повноважень не покладає, хоча, на нашу думку, кооперація державних органів в усіх сферах повинна вважатися як презумпція у будь-якому разі, коли держава має вирішувати певну проблему. Зокрема для Міністерства юстиції та Державної служби з питань праці це інформаційна політика, а саме співпраця в сфері створення й ефективної роботи реєстрів для моніторингу й аналізу ризикових точок порушення трудових прав працівників.

3 іншого боку, новий проект Трудового кодексу, внесений Верховною Радою України IX скликання, покликаний кардинально змінити сучасне трудове законодавство, зокрема додавши детальне регулювання прав і обов'язків працівника та роботодавця, надавши їх вичерпний перелік, встановлює конкретні засоби протидії рабської праці та дискримінації у сфері праці.

Але навіть у сучасному проекті Трудового кодексу України регулювання процедури укладання трудового договору залишилося доволі обмеженим, а саме лише через укладання класичного трудового договору або видання наказу про призначення працівника. Важливим є те, що сама процедура призначення або укладання договору не визначена, тобто про строки, у які роботодавець повинен укласти договір або видати наказ про прийняття працівника на роботу, новий Трудовий кодекс прямо не вказує, що знову дає поле для зловживання роботодавцем при прийнятті працівника на роботу.

Покарання за допуск працівника до роботи без укладання трудового договору складають десять мінімальних заробітних плат, що є у три рази нижчим штрафу, який передбачається на цей час, але інші санкції за порушення виплати заробітної плати або недотримання соціальних гарантій є вищими. Таким чином законодавець, знизивши відповідальність за неоформлених працівників, підвищив відповідальність роботодавця за порушення трудового законодавства в цілому, що може призвести до ефективного захисту трудових прав при кумулятивному застосуванні санкцій [6].

Проаналізувавши стан захисту трудових прав працівника, ми можемо зробити такі висновки та надати пропозиції:

1. Система захисту трудових прав потребує вдосконалення та більш детальної регламентованості відповідно до потреб сучасного суспільства. Виникнення нових типів роботи, можливості вибору самостійно робочого місця або зміна регулювання самого факту наявності трудових відносин примушує сучасного законодавця вносити зміни в Кодекс Законів про працю України, хоча $б з$ доповненням його нормами щодо регулювання сторонами відносин на власний розсуд у межах трудового законодавства. Водночас сторони вимушені регулювати власні відносини, спираючись на положення Цивільного кодексу України щодо договорів підряду, які позбавлені необхідних рис права на працю та трудових гарантій, що виходять з нього.

2. Застаріле законодавство дає багато можливостей для зловживання роботодавцями прогалинами у ньому на свою користь задля експлуатації працівника та зменшення обсягу наданих йому прав. Все це є наслідком небажання працівників підвищувати власну правосвідомість i використовувати права надані їм законодавством. Окремо потрібно виділити бездіяльність державних органів влади у сфері боротьби з незадекларованою працею, яка породжує уникнення відповідальності недобросовісними роботодавцями та підтримує можливість існування «чорної» або нелегальної праці.

Виходячи з аналізу законодавства та наукових праць, пропонуємо наступні зміни до ч. 1 ст. 24 КЗпП, виклавши її в такій редакції:

«Стаття 24 Укладання трудового договору.

Трудовий договір між працівником і роботодавцем укладається завжди у письмовій формі, 3 обов'язковим ознайомленням працівника 3 договором і його підписом. Відсутність письмового трудового договору, навіть якщо сторони дійшли домовленостей з усіх сутнісних умов праці, оплати праці та трудового розпорядку, вважається таким, що неукладений, а працівник - допущеним до роботи без укладання трудового договору. Допускається регулювання трудових відносин між працівником і роботодавцем на власний розсуд, з обов'язковим включенням основних прав та обов'язків сторін, а також соціальних гарантій працівника, встановлених цим Кодексом, у разі суперечностей положення трудового договору та цього Кодексу, до трудових відносин застосовуються положення цього кодексу». 


\section{Jimepamypa}

1. Конституція України. Відомості Верховної Ради України. 1996. URL: https://zakon.rada.gov.ua/ laws/show $/ 254 \%$ D0 $\%$ BA $/ 96-\%$ D0 $\%$ B2 $\%$ D $1 \% 80$.

2. Загальна декларація прав людини. Відомості Верховної Ради України. 1948. URL: https://zakon. rada.gov.ua/laws/show/995_015.

3. Кодекс законів про працю України. Відомості Верховної Ради України. 1971. URL: https://zakon. rada.gov.ua/laws/main/322-08.

4. Меморандум про співробітництво між Державною службою України з питань працю та Міністерством юстиції України. Українське національне інформаційне агентство «Укрінфорл». 2019. URL: https://www. ukrinform.ua/ rubric-presshall/2622089-pidpisannamemorandumiv-pro-spivrobitnictvo-miz-ministerstvomusticii-ukraini-i-derzavnou-sluzbou-zajnatosti-taderzavnou-sluzbou-ukraini-z-pitan-praci.html.

5. Ваше відношення до неофіційного працевлашування. 2019. URL: https://docs.google.com/forms/ d/e/1FAIpQLSeCEHvmMGXMdCzy6V0yVMP0EtJOtZX m1G2BK3hpUdXEcf1Tyw/viewform.

6. Проект Трудового кодексу України. Вiдолості Верховної Ради України. 2019. URL: http://w1.c1.rada. gov.ua/pls/zweb2/webproc4 1?pf3511=67331.

7. Публічний звіт голови Державної служби України 3 питань праці Романа Чернеги. Українське національне інформаційне агентство "Укрінфорл». 2018. URL: https://www.ukrinform.ua/ rubric-presshall/2638814-pidsumki-roboti-derzavnoisluzbi-ukraini-z-pitan-praci-za-2018-rik.html.

8. Горденюк А.О. Проблема правового забезпечення захисту трудових прав працівників. Форум пра ва. 2016. № 1. C. 55-59. URL: http://nbuv.gov.ua/jpdf/FP-index.htm 2016_1 11.pdf.

9. Гуменюк I.O. П̄равові проблеми захисту трудових прав в умовах реформування соціально-економічної сфери. URL: http://ir.znau.edu.ua/ bitstream/123456789/1700/1/Pravo_2014_150-152. pdf.

10. Єфімов H.I. Проблеми легалізації соціально-трудових відносин в України. Харків : Харківський регіональний інститут державного управління, 2019. 4 c.

\section{Анотація}

Пряміuин В. Ю., Ланкін С. В. Захист трудових прав працівників у неоформлених трудових відносинах. - Стаття.

У статті досліджується захист права на працю та проблема незадекларованих трудових відносин із позиції органів державної влади та суду, також позиція роботодавців і працівників у їх взаємовідносинах і чинники цього правопорушення.

Оскільки сучасний стан дотримання трудового законодавства роботодавцями в Україні є низьким, вивчення проблеми незадекларованої праці потребує всебічного вивчення для винайдення шляхів для захисту трудових відносин працівника від експлуатації та зловживання на усіх етапах правовідносин із роботодавцем.

Також особливо варто виділити необхідність реформування державних органів із питань захисту трудових прав працівників задля підвищення їх ефективності та реального притягнення роботодавців правопорушників до юридичної відповідальності в найбільш короткі строки з дня виявлення порушення трудових прав на підприємстві.

Необхідною мірою задля усунення порушень трудових прав громадян України є прийняття законодавчим органом влади нового зводу законів про працю, який зміг би оновити та врегулювати новітні трудові відносини між працівником і роботодавцем із можливістю включення в нього більшою мірою диспозитивних норм, тобто регулювання трудових відносин на власний розсуд з імперативними нормами з приводу трудових гарантій працівника та встановлення суттєвої матеріальної відповідальності за порушення основних положень трудового законодавства.

Загалом для встановлення ефективного правового режиму у сучасному трудовому секторі України держава потребує великої державної реформи з залученням усіх гілок влади та сприянням зацікавлених працюючих громадян, профспілок, громадських організацій, засобів масової інформації тощо.

Ключові слова: неоформлені трудові відносини, незадекларована праця право на працю, захист права на працю, юридична відповідальність.

\section{Summary}

Pryamitsyn V. Yu., Lankin S. V. Protection of labor rights of workers in unformed labor relations. - Article.

The article examines the protection of the right to work, and the problem of undeclared employment relations, from the standpoint of public authorities and the court, as well as the position of employers and employees in their relations and the factors of this offense.

As the current state of compliance with the labor laws by employers in Ukraine is quite low, studying the problem of undeclared work requires a thorough study to find ways to protect the employee's employment from exploitation and abuse at all stages of the relationship with the employer.

The need to reform state bodies for the protection of workers 'labor rights in order to increase their efficiency and real prosecution of the offenders' employers in the shortest possible time after the detection of violations of labor rights in the enterprise is especially worth mentioning.

At the same time, in order to eliminate the violations of the labor rights of Ukrainian citizens, a new body of labor laws could be adopted by the legislature, which could update and regulate the latest labor relations between the employee and the employer, with the possibility of incorporating more dispositive regulations into it. relations at its own discretion with imperative norms regarding the employee's labor guarantees and the establishment of material liability for violation of the basic provisions of labor law enters.

In general, in order to establish an effective legal regime in the modern labor sector of Ukraine, the state needs a major state reform with the involvement of all branches of government and with the assistance of interested working citizens, trade unions, public organizations, mass media, etc.

Key words: unformed labor relations, undeclared work, right to work, protection of the right to work, legal responsibility. 